\title{
Classroom Management Experiences with Syrian Refugee Students
}

\author{
Emine Saklan 1, *, Aysun Erginer ${ }^{2}$ \\ ${ }^{1}$ Faculty of Education, Department of Educational Sciences, Gaziosmanpasa University, Tokat, Turkey \\ ${ }^{2}$ Faculty of Education, Department of Primary Education, Nevsehir Haci Bektas Veli University, Nevsehir, Turkey
}

\section{Email address:}

eminesaklan@gmail.com (E. Saklan), aysunerginer@nevsehir.edu.tr (A. Erginer)

${ }^{*}$ Corresponding author

\section{To cite this article:}

Emine Saklan, Aysun Erginer. Classroom Management Experiences with Syrian Refugee Students. Education Journal. Vol. 6, No. 6, 2017, pp. 207-214. doi: 10.11648/j.edu.20170606.17

Received: December 8, 2017; Accepted: December 27, 2017; Published: December 28, 2017

\begin{abstract}
The purpose of this study was to evaluate classroom management experiences with Syrian refugee students from the perspective of teachers. The study has a qualitative design and uses the case study method. The study group of this research was teachers in primary and middle schools in the central district of Tokat province who taught Syrian refugee students who had been forced to migrate to Turkey. This research found that most of the teachers' classroom management experiences with Syrian refugee students had negative aspects, and that the teachers stressed their linguistic challenges. It was found that refugee students' pronunciation problems had caused them to be ridiculed. Teachers stated that they did not know what to do when they encountered with communication problems with these students. A variety of events (in-class activities, school trips, etc.) should be planned to prevent the other students from being biased against the Syrian refugee students and enable both groups to be integrated. Teachers' awareness on how to behave with Syrian refugee students should be raised through the in-service training.
\end{abstract}

Keywords: Migration, Syrian Refugee Students, Classroom Management

\section{Introduction}

Migration is a phenomenon that has a great impact on individuals, families, countries and communities. Particularly individuals who migrate; families, the countries who has immigration and emigration are influenced by migration socially, culturally, economically, demographically, politically, spiritually and educationally [12]. The group most affected by the adverse conditions created by migration is undoubtedly the children. Almost half of the refugees $(51.9 \%)$ who forced to migrate from Syria to Turkey $(3,097,390)$ are children (0-18 years) [38]. Nearly half of the children who migrated from Syria has no opportunity to access education, for this reason [1]; [39]; [22] enrolment to school rates are declined; the problems like the number of schools do not meet the demand of increasing population is arise, classes become crowded day by day, families cannot devote resources to education, the children experience understanding and speaking problems to educational language [36]; [37] and teachers motivation is affected negatively [24]. It is necessary to minimize the problems in the classroom to function the teaching-learning process effectively and provide a healthy learning environment [16].

Classroom management is a set of techniques and activities related to control, change and organize the teaching environment and students' attitudes towards the classroom goals. In addition, classroom management can be defined as creating and sustaining a learning environment that provides both effective and qualified training system, improving the working conditions of the class and destroying any distractions that may arise [27]. However, the students from different cultural background studying in the same classes might bring some classroom management problems. Nevertheless, the importance of classroom management approaches and methods cannot be denied at the point of refugee students' adaptation to a new society, their schools, teachers and friends.

Refugee students come from many different countries and socioeconomic, political, linguistic and ethnic origins. The 
experiences of children in the past are influential in their relationships with their schools, teachers and friends. In particular, preliminary experiences of refugee students are significantly reflected in their academic careers. Many refugee children are exposed to disruption in education and have limited opportunities to go to school. In addition, they encounter some language-based problems [13].

Due to the changing demographics around the world, cultural diversity is now the norm in many schools. For this reason, it becomes a necessity for teachers and education administrators to be aware of the cultures, languages and characteristics of the students in their schools. Ethnic and cultural differences also require restructuring and alteration of educational systems and processes and revision of educational policies and philosophies that reflect multicultural parameters and contexts. One of the most difficult topics in multicultural education is classroom management. Prior to the techniques and approaches to classroom management, the values, norms and beliefs of dominant cultures had to be considered. In classroom management approaches of the past that reflect the values, norms and beliefs of dominant cultures, the tendency to change the academic, sociocultural, developmental, moral and ethical needs of growing number of ethnically diverse school population must be pursued [19].

The phenomenon of migration in the world affects schools as well and requires the development of the knowledge and skills teachers should possess. Because of the increasing cultural diversity in the classroom, teachers are expected to focus on learning and improving the learning of all students by preparing themselves to struggle with difficulties (Ladson-Billings 1995; as quoted in [34]). Teachers should also be aware of the specific needs of students from different cultures and know how to apply specific instructional strategies and interpersonal cues to create a positive classroom environment and meet the needs of various students (Wubbels et al., 2006; as quoted in [34]). In multicultural settings, teachers often have to deal with tensions with students with different backgrounds. The knowledge and skills teachers should have to deal with these critical situations often remain inadequate. Teachers have become more sensitive to intercultural issues in order to cope with these problems (Ladson-Billings 1995; Radstake 2009; as quoted in [34]).

Teachers must be culturally literate. Cultural literacy can be achieved through a comprehensive knowledge of ethnic and racial groups' histories, social patterns, traditions, habits, family characteristics, values and educational challenges. Being culturally illiterate can create serious threats to the health and well-being of students. Teachers may be trying to solve problems that are not available, or they may not be able to recognize existing problems, or they may use culturally ineffective strategies to solve problems that may arise. These attitudes can trigger feelings of alienation, anger, helplessness, normlessness and insecurity among students. These emotions can ultimately lead to exclusionary behaviors (eg, flagrant aggression, destruction of school property, violence against others, opposition) or internalizing behaviors (eg depression, anxiety, out of school and classroom activities, extreme fears) [19].

Although the culture and education students have acquired before immigration have a profound effect on the success of the students in the school, the performance of refugee students is more related to the characteristics of the school system in the host country. School systems play a major role in the integration of refugee students, and some countries are better at improving the skills of students with different intellectual and cultural backgrounds than others. Refugee students' psychological well-being does not only depend on the differences in their own countries and the countries they emigrate to. It also depends on how well the schools in the host countries and the local communities help them to overcome the numerous challenges they face to succeed in school and build a new life [28].

Refugee students tend to struggle with socio-emotional problems, and these socio-emotional problems can affect their learning (McBrien, 2005; Oh \& Stouwe, 2008; as quoted in [10]), according to a large number of studies in the United States and a survey in Thai border camps. Refugee children in the United States tend to have high rates of depression and anxiety and often fight post-traumatic stress syndrome (PTSD, Lustig et al., 2004; as quoted in [10]). Many refugee students are overly shy, withdrawn, unconcerned and unmotivated to learn. They are silent in lessons and they do not establish eye contact with the teacher. They usually have destructive feelings such as anger and frustration [10].

Ethnic groups clash at schools and this weakens group affiliation among students. In many countries there is no good relationship between students with different ethnic origins. In some countries, violent tendencies continue among students from different ethnic backgrounds. Hostilities and competition are also reflected in classes, preventing proper behavior and motivating lessons (2004, 38). Immigrant students face many problems both inside and outside the school, and this affects their behaviour and learning. Teachers should be sensitive about this and help students [20].

Studies conducted until 2012 show that teachers are inadequate to meet the needs of refugee students and sometimes it is difficult for teachers to determine which students are refugees in their class (Alisic, Bus, Dulack, Pennings, Splinter, 2012; as quoted in [9]). Refugee families have stated that their children are not respected and not supported by teachers because of their inability to speak English at the same level as their peers (Gagné, 2012, 35; as quoted in [9]). Refugee and refugee students have not been able to adapt to Canadian classes due to poor student- teacher relations. As a result, refugee students find their teachers "distant, indifferent and irrelevant" (Yau, 1996, 12; as quoted in [9]).

As the population of Syrian refugee students in Canada continues to increase, educators will need to adopt some educational strategies to respond to the needs of these new 
students. Three strategies that teachers can use to facilitate the learning and integration of newly arrived Syrian refugee students can be suggested. These are to focus on language needs, to establish positive relationships and to create a safe learning environment. Participating in pedagogical activities that encourage a safe learning environment can help to remove the barriers faced by Syrian refugee students and allow them to get used to new class communities more quickly and easily [9].

Managing classes in which there are students from different cultures are located and having to cope with certain behaviors is a condition that puts strain on all stake holders. Especially less experienced teachers are faced with various difficulties in classrooms where refugee students are located. In this case there may be conflicts in the class, misunderstanding of behaviors can lead to communication problems, disciplinary issues may arise and teacher-student interaction may be negatively affected [5]. In their study Saglam and Ilksen Kanbur (2017) have found that, primary school teachers competencies to train refugee students are not at the desired level and that they have not received sufficient training on this issue. A similar situation can be observed in Polat and Rengi's research (2014). In that research, primary school teachers reported that they felt they did not have sufficient skills to treat students with different cultural characteristics and that they had problems communicating with students from different cultural backgrounds. Also, Saglam and Ilksen Kanbur (2017) expressed that while female teachers felt less competent in comparison to male teachers in maintaining classroom management while teaching and highlighted that educating refugee students is challenging.

Classroom management approaches may differ from culture to culture, but these approaches are more likely to be more dependent on local conditions than cultures. For example, comprehensive migration in Israel has created a special need for classroom management as a mean to socialize students in Israeli society [41]. Classroom management can show cultural and local characteristics, while teachers need to have certain competences to manage the class effectively even in normal classes, the situation become more difficult in multicultural classes, too. Using some strategies in classroom management can be effective on all students as well as on refugee students. These: "Using activities that involve the students moving around, teaching songs, making lessons fun, using humor and interactive activities to build cooperation, providing lots of opportunities for repetition and recycling, maintaining a fast pace of activities to keep learners' attention" [6].

This study is intended to evaluate classroom management experiences with Syrian refugee students from the perspective of teachers. It asked the following questions:

1. What are the positive or negative aspects of having Syrian refugee students in classes, and how do they affect classroom management?

2. What are the themes of these experiences?

\section{Methods}

\subsection{Research Model}

The study has a qualitative design and uses the case study method. Case studies are used to seek answers to scientific questions. Data were collected in interviews [7].

\subsection{Study Group}

The study group of this research was teachers in primary and middle schools in the central district of Tokat province who taught Syrian refugee students who had been forced to migrate to Turkey. The study included 18 teachers who agreed to participate. The researchers made appointments with the teachers for face-to-face interviews and assured them of the confidentiality of the research. They asked the participants for personal and professional information, their field of study and their gender. Table 1 shows this information.

Table 1. Demographic Characteristics of the Participants.

\begin{tabular}{llll}
\hline Variables & Level & $\boldsymbol{f}$ & $\%$ \\
\hline \multirow{2}{*}{ Sex } & Female & 4 & 22,22 \\
& Male & 14 & 77,78 \\
& Department of Classroom Teacher & 7 & 38,89 \\
& Department of Turkish Language & 2 & 11,11 \\
Field of & Department of Math & 3 & 16,67 \\
Study & Department of Religious Culture and & 1 & 5,56 \\
& Moral Education & 3 & 16,67 \\
& Department of Science & 2 & 11,11 \\
& Department of Social Studies & 2 & 11,11 \\
& 1-5 years & 12 & 66,67 \\
& 6-10 years & 2 & 11,11 \\
Experience & 11-15 years & 1 & 5,56 \\
& 16-20 years & 1 & 5,56 \\
\hline
\end{tabular}

The participants were determined using criterion sampling [26]. The criterion for inclusion in this research was for the teachers to have Syrian refugee students in their classes. Primary and middle schools where Syrian refugee students studied were selected, and voluntary interviews were conducted with 18 teachers (7 primary school teachers, 11 secondary school teachers).

\subsection{Limitations}

The research was limited to teachers who worked in Tokat province during the 2015-2016 academic year and taught Syrian refugee students.

\subsection{Data Collection}

The views of the participants were determined using a semi-structured qualitative interview form as a data collection tool. During the preparation and administration of the semi-structured interview form, some measures to enhance internal validity were taken. The available literature on classroom management was examined at the stage of preparing the interview form. To determine the personal 
information of the participants, they were asked three questions. To determine their views on classroom management, they were asked: "What are the positive or negative aspects of having Syrian refugee students in your classes, and how do they affect classroom management?"

Data were collected in interviews done 18 teachers who worked in the primary and middle schools in the central district of Tokat province and taught Syrian refugee students who had been forced to migrate to Turkey. All interviews and encoding procedures were conducted by the same researchers. The researchers made an appointment with the participants and conducted the interviews in settings chosen by them. Each participant was interviewed for 10-30 minutes. The interviews were recorded by permission of the participants to avoid data loss. The answers were transcribed by the researchers. The texts were checked for completeness and accuracy.

\subsection{Data Analysis}

The data from the interviews were analyzed using content analysis. Content analysis discloses themes that were not explicit beforehand. Content analysis categorizes similar data by theme, and organizing and interpreting them to be understood by readers [42].

Each interview form was encoded as T1, T2, T3 and so on for the teachers during data analysis. The answers were scrutinized by the researchers and encoded based the participants' expressions with no predetermined code content. During encoding, the frequency of expressions was identified. The codes were gathered, their similarities and differences were examined, and after the common features of similar codes were identified, themes were created [14]; [42]. The data were reviewed, the two researchers' codes and themes were compared to each other, and they were finalized and expressed so as to be understood by readers. Since the qualitative data could be reduced in number at a certain level, the frequency of the codes and the themes were calculated. The participants' personal expressions were presented in quotation marks and with no change. The resulting data were examined based on their cause and effect relationships, and consequently several judgments were acquired [42].

\section{Findings}

This section includes the findings obtained from the participants.

Table 2. The Teachers' Views on Positive and Negative Classroom Management Experiences with Syrian Refugee Students.

\begin{tabular}{lll}
\hline Theme & Teacher No. & $\boldsymbol{N}$ \\
\hline Positive & T14, T18 & 2 \\
Negative & T1, T2, T3, T4, T5, T6, T7, T8, T9, T10, T11, T12, T13, T15, T16, T17 & 16 \\
\hline
\end{tabular}

Table 2 shows that most of the experiences were negative. However, two of the teachers had positive experiences.

Table 3. The Teachers' Views on Classroom Management Experiences with Syrian Refugee Students.

\begin{tabular}{ll}
\hline Theme & Teacher No. \\
\hline Linguistic challenges & T1, T2, T4, T5, T9, T10, T13, T14 \\
Non-accommodation & T3, T11, T15, T16 \\
Non-acceptance of the Syrian refugee students by the Turkish students & T6, T17 \\
Absenteeism & T12 \\
Non-observance of the classroom rules and behaving poorly & T8 \\
Non-engagement in class & T7 \\
Adaptation and achievement & T18 \\
\hline
\end{tabular}

Table 3 shows the factors in the teachers' classroom management experiences with Syrian refugee students. They included: linguistic challenges, non-accommodation, nonacceptance by the other students, absenteeism, nonobservance of the classroom rules and behaving unfavorably and non-engagement in class. The teachers noted that they mostly experienced linguistic challenges about the Syrian refugee students, and this affected classroom management. They added that linguistic challenges prevented them from understanding the lessons and distracted them. The Syrian refugee students made fools of themselves by mispronouncing words. This disturbed the female refugee students most and caused them to become withdrawn. They also stated that since these students could not understand Turkish, some students took advantage of this. They finally emphasized that the other students in the classroom had misconceptions about the Syrian refugee students and considered their teacher's helping these students as discrimination. Here are some of the teachers' views on this issue:

I do not know what to do when the Syrian refugee students cannot understand the examples I give in the class. I try to find the Arabic equivalents of the words. Meanwhile, the other students are distracted, and it takes a long time to get them to concentrate again (T1).

The Syrian refugee students make fools of themselves when they cannot pronounce some words correctly, and this situation causes the female refugee students to become withdrawn and isolate themselves (T2).

Unfortunately, some of the other students try to teach the Syrian refugee students offensive and obscene words. Since they do not know the meaning of what they are saying, they may become a standing joke (T4).

In the religious culture and moral education lesson, one of the students said, 'Teacher! You should ask the suras to the Syrian students. I know Turkish, not Arabic.' When the 
teacher asked a Syrian student about them, the student was unable to reply. 'I know Arabic, but I do not know the meaning of the suras. And I do not think you know their Turkish meaning, too' (T10).

I help two of the Syrian students in my classroom particularly with sections that they cannot read or understand. Their improvement is slightly better than the first year. They have begun to speak Turkish better, but they are still inadequate. One of these days, I was helping them in an exam, and one of the other students jumped on me, saying: 'Why do you help them? They will get high grades.' I told the student that this was not discrimination, and they would not get high grades anyway. I do not want to hurt my other students because of two people. Frankly, I do not know what to do in such cases. When my Syrian students get such reactions from their Turkish friends, they become far more withdrawn and do not want to come to school. And in some parts of my lessons, I try to explain their situation to my other students (T13).

Linguistic challenges also lead to cultural problems and indifference on the part of teachers. One of the teachers said:

I did not notice the presence of a refugee student in my classroom for a long time. This student was neither speaking, nor being engaged in the class. This student did not make friends with the other students. One day, I asked this student a question and the student replied, 'I do not understand.' Then I realized that the student was a refugee, and afterwards, I began to treat this student differently (T5).

One of the teachers drew attention to the point that linguistic challenges can positively affect Syrian refugee students:

A student of mine who had been the top student in Syria participated in our class as an eighth grader. Later, the student tried to learn Turkish, but did not understand any of our words for approximately three months, only looking the mathematical formulas we wrote on the board. Since math is mostly practical, the student actually began to understand some points, but we were not aware of this. Additionally, the public education centers opened free Turkish courses, and the student strove to learn Turkish by attending one of these courses. Thanks to individual effort and intelligence, the student got the highest math grade at the end of the term (T14).

The teachers reported that the Syrian refugee students had accommodation problems that affected classroom management. They added that their lessons were hindered, the Syrian refugee students could not get used to their situation and missed their own country and friends. Here are some of the teachers' opinions about this issue:

I fall behind in the topics I should teach simply to ensure that the refugee students accommodate themselves to the class (T3).

I have a Syrian female student. She is quite withdrawn in classroom and non-classroom activities. She does not have many friends. When I asked her why, she said that she deeply missed her friends in her own country and her old school. She mentioned that she had accommodation problems here.
She also stated that she was not interested in the lessons much to protest the events occurring in her country and her current experiences (T11).

The refugee students do not want to come to school since they have not adequately embraced school. They were occasionally excluded by their peers, and no adequate orientation was conducted in the school. Sometimes they do not come to school for weeks (T15).

They can strike an aggressive attitude towards their friends. The reason for this is that they gave up their own culture, habits, customs and everything (T16).

Some of the teachers stated that the other students in the classroom would not accept the Syrian refugee students, excluded these students from their playing and considered them as a threat, underlining the refugees' effects on classroom management. These teachers said:

Our students regard the Syrian refugee students as if they will return to their country at any moment. Therefore, they do not let them join in their playing. These students feel left out (T6).

My students think that the Syrian refugee students will affect their job opportunities. They also exhibit heartbreaking behavior, such as harshly asking them, 'Why did you come here?' 'Why didn't you stay to defend your country?' 'Why did you abandon your country?' 'Why aren't you fighting?' (T17).

One of the teachers reported that since moving to another country again is at issue, the Syrian refugee students engage in absenteeism. This teacher said:

There was a Syrian student who was absent many times. In fact, they would leave Turkey this year. The student was absent many more times at the end of the year. At first, the student was absent because the other children were poking fun. Then the student grew accustomed, a little bit, and then the student had to go again (T12).

One of my friends was teaching first graders in the primary school. My friend had a Syrian student and explained that this student had an absenteeism problem. My friend said the student was continuously crying at school. My friend thought that failing to attend the orientation and learn Turkish had caused this problem (T12).

One of the teachers (T8) experienced an event in which one of the Syrian refugee students did not observe classroom rules and behaved poorly:

One afternoon, one of my refugee students was late for the class probably because the student was working somewhere. I told the student to wait outside the classroom. After all, the student interrupted the lesson and caused to discipline problems. When I told the student to wait outside, the student splashed water on me. I did not make something out of nothing (T8).

One of the teachers (T7) stated that a refugee student was not engaged in class for fear of being mocked:

I asked one of my refugee students their reason for not engaging in class. The student explained that it was fear of being mocked for giving incorrect answers (T7).

One of the teachers (T18) stated that unlike refugee 
students from other countries, the Syrian refugee students did not have accommodation problems and generally succeeded in class:

Although the Syrians do not come to stay here permanently, we can say that they behave more positively than others in accommodating themselves. Whereas the refugee students from other countries are not so successful, Syrian refugee students, including members of the Turkmen and other communities, are more successful and coherent (T18).

\section{Conclusions}

This research found that most of the teachers' classroom management experiences with Syrian refugee students had negative aspects, and that the teachers stressed their linguistic challenges. In literature, especially language problems were emphasized with regard to refugee students [2]; [25]; [11]; [40]; [15]; [23]; [8]; [31]; [33]; [17]; [35]; [29]; [30]. [3] stated that some of the refugee students experience problems in their academic life and communicating with others because of differences in Turkish pronunciation. Similarly, in this study, it was found that refugee students' pronunciation problems had caused them to be ridiculed and this finding coincided with the findings of [17]. In the same research, lack of orientation program for teachers about refugee students caused teachers to experience problems about how to approach to these students. In this study, teachers stated that they did not know what to do when they encountered with communication problems with these students. In their study, [40] found that refugee students were ignored from time to time and this finding is similar in this study, too. However, according to [33], language problems had not been a top priority as in this research.

In this research, only one teacher had a positive attitude, stating that linguistic challenges could be overcome referring to a Syrian refugee student. The other classroom management factor emphasized most was nonaccommodation. In literature, accommodation problems of refugee students were also seen as an underlying issue [25]; [23]; [8]; [3]; [33]; [17]; [4]; [35]; [29]; [30]; [21]; [18].

The Syrian refugee students, who had to maintain their lives and education in a different country for a variety of reasons, had accommodation problems during their education. The teachers also underlined that the other students would not accept the Syrian refugee students. In their study, [17] found that Turkish students had found it hard to accept refugee students. They could only accept these students with the help of their teachers. This finding was same with current study's findings. In addition, unlike this research's findings, they stated that refugee students were placed to classes regardless of considering their educational qualifications and this caused educational failure. In [33] study, different from this research's findings, it is pointed out that the first difficulty experienced by refugee students was adaptation process to the environment. In their studies as in this study [25], [3] and [29] found that refugee students were alienated by their peers and they were not included in the games and also [25] noted that these students behave in an introverted and aggressive manner. In [29] study, unlike this study, it is stated that other students perpetrated psychological and physical force to refugee students. In [30] study, it is figured out that students had perpetrated physical and verbal violence to each other, furthermore, they damaged to school course materials because they were failed to adopt the school environment.

The teachers reported that the Syrian refugee students were absent because of frequently moving, and this caused problems for themselves and classroom management. The research findings also indicated that the Syrian refugee students did not observe classroom rules, behaved poorly and were not engaged in the class. Refugee students were late for class and they had absenteeism problems because they had to work for their own living [2]; [11]; [8]; [30]. Even different from this research, in some studies, it was found that refugee students escaped from the school [30] and school drops were occured [2]; [11]; [15]. In his study, [15] also emphasized to child begging and stated that children begged something from their teachers and principals.

However, one of the teachers had a positive attitude and said that the Syrian refugee students accommodate themselves more easily than other refugee students.

\section{Recommendations}

1. In order to enable Syrian refugee students to overcome linguistic challenges, Turkish language programs should be popularized, and these students should be enabled to benefit from them.

2. Orientation activities that will help Syrian refugee students accommodate themselves to Turkey and the cities they live in should be planned and involve their families.

3. The reasons for the Syrian refugee students' absenteeism should be determined with current monitoring mechanisms and it should be encouraged to attend school.

4. Teachers' awareness on how to behave with Syrian refugee students should be raised through the in-service training.

5. A variety of events (in-class activities, school trips, etc.) should be planned to prevent the other students from being biased against the Syrian refugee students and enable both groups to be integrated.

\section{Notes}

A previous version of this paper was presented at the ISNITE 2016 Symposium.

\section{References}

[1] AFAD. (2013). Syrian refugees in Turkey: 2013 field survey results. Ankara: Republic of Turkey Prime Ministry Disaster and Emergency Management Presidency. 
[2] Avci, F. (2016). Turkiye'deki Suriyeli siginmacilarin egitim sorunlarina yonelik izlenen politikalar ve ulasilan cozumler (Educational policies and accessible solutions for the issues of Syrian refugees in Turkey). Paper presented at the annual meeting for the 25. National Congress of Educational Sciences, Antalya, Turkiye, April 21-24.

[3] Balkanlioglu, R. (2014). Gocun Ogrencinin Egitim Yasantisi Uzerindeki Etkisi (The Effect of Migration on Student's Educational Experience). $\mathrm{PhD}$ diss., University of Dumlupinar.

[4] BIAMER. (2014). Final report of the workshop the issues of Syrian immigrants. Mersin University: The Regional Monitoring Research and Application Center.

[5] Boru, N. and Boyac1, A. (2016). Gocmen ogrencilerin egitimogretim ortamlarında karșılaştıkları sorunlar: Eskisehir ili ornegi (Immigrant students' problems in education-instruction processes (an example of the province of Eskisehir). International Periodical for the Languages, Literature and History of Turkish or Turkic, 11 (14), 123-158.

[6] Burgoyne, U. and Hull, O. (2007). Classroom management strategies to address the needs of Sudanese refugee learners. An adult literacy national project report. Australia: NCVER.

[7] Buyukozturk, S., Kilic Cakmak, E., Akgun, O. E., Karadeniz, S. and Demirel, F. (2014). Bilimsel arastirma yontemleri (Scientific research methods). (18. ed.). Ankara: Pegem.

[8] Cakmak, E. and Yildirim, K. (2015). Multeci ogrencilerin ogretim-ogrenme durumlarinin Turkce dil becerileri baglaminda incelenmesi: Aksaray ili ornegi (The examination of Refugee students' teaching-learning situation in the context of Turkish language skills: The sample of Aksaray province). Paper presented at the annual meeting for the 24. National Congress of Educational Sciences, Nigde, Turkiye, April 1618 .

[9] Clark, K. A. (2017). Are We Ready? Examining Teachers' Experiences Supporting the Transition of Newly-Arrived Syrian Refugee Students to the Canadian Elementary Classroom. Master diss., University of Toronto.

[10] O’Neal, C., Atapattu, R., Jegathesan, A., Clement, J., Ong, E. and Ganesan, A. (2016). Classroom management and socioemotional functioning of burmese refugee students in Malaysia, Journal of Educational and Psychological Consultation, DOI: 10.1080/10474412.2016.1193740.

[11] Demirel, M. and Capur, A. (2016). Suriyeli multecilerin egitim sorunu: Goc sureci ve sonrasi (The problem of Syrian refugees' education: The process of migration and post). Paper presented at the annual meeting for the 25. National Congress of Educational Sciences, Antalya, Turkiye, April 2124.

[12] Demirhan, Y. and Aslan, S. (2015). Trans-Border Migration Policies and Administration of Turkey, Journal of Individual and Society, 5 (9), 23-62.

[13] Dryden-Peterson, S. (2015). The educational experiences of refugee children in countries of first asylum. Washington DC: Migration Policy Institute.

[14] Ekiz, D. (2009). Bilimsel arastirma yontemleri (Scientific research methods). (2.ed.). Ankara: Ani.

[15] Emin, M. N. (2016). Turkiye'deki Suriyeli cocuklarin egitimi temel egitim politikalari (Main education policies on the education of Syrian children in Turkey). SETA: Istanbul.

[16] Erden, M. (2005). Sinif yonetimi (Classroom management). Istanbul: Epsilon.

[17] Eres, F. and Tetik, S. (2014). Gocmen ogrencilere egitim veren ogretmenlerin sorunlari: Tokat ornegi (The problems of teachers in providing education for immigrant students: The sample of Tokat province). Paper presented at the annual meeting for the 23. National Congress of Educational Sciences, Kocaeli, Turkiye, September 04-06.

[18] Expósito, S. and Favela, A. (2003). Reflective voices: Valuing immigrant students and teaching with ideological clarity. The Urban Review, 35 (1), 73-91.

[19] Gabriel, E.; Woolford-Hunt, C. and Matthews, L. (2010). Culturally relevant approaches to classroom management, Teaching \& Professional Practice, 4 (1), 10-13.

[20] Grossman, H. (2004) Classroom behavior management for diverse and inclusive schools. USA: Rowman \& Littlefield Publishers.

[21] Han, T. (2010). Goc Eden Ailelerin Cocuklarinin Egitim ve Ogretimde Karsilastiklari Uyum Sorunlari. Master diss., University of Ankara.

[22] HNO (Humanitarian Needs Overview). (2016). Retrieved from http://hno-syria.org/\#key-figures

[23] Human Rights Watch. (2015). Preventing a Lost Generation: Turkey. "When I Picture My Future, I See Nothing" Barriers to Education for Syrian Refugee Children in Turkey. Retrieved from http://www.hrw.org

[24] Karakus, E. (2006). Goc Olgusu ve Egitime Olumsuz Etkileri (Sultanbeyli Ornegi) (Migration phenomenon and its negative effects on education "The rase of Sultanbeyli"). Master diss., University of Sakarya.

[25] Keskinkilic-Kara, S. B. and Senturk-Tuysuzer, B. (2016). Siginmaci ogrenciler ve egitim surecinde yasanan sorunlara iliskin yonetici ogretmen ve veli gorusleri. Paper presented at the annual meeting for the 25. National Congress of Educational Sciences, Antalya, Turkiye, April 21-24.

[26] Miles, M. B., Huberman, A. M. and Saldana, J. (1994). Qualitative data analysis: An expanded source book. (2.ed.). California, USA: Sage.

[27] Nacino-Brown, R., Oke, F. E. and Brown, P. D. (1982). Curriculum and instruction: An introduction to methods of teaching. Hong Kong: The Macmillan Press.

[28] OECD (2015). Helping immigrant students to succeed at school-and beyond. Retrieved from $\mathrm{http}: / /$ www.oecd.org/migration-insights/

[29] Oner, C. (2010). Avrupa birligi uyelik muzakereleri cercevesinde Van ilindeki multecilerin sorunlari (The problemse of refugees live in Van in accordance with European Unionnegotiation). Master diss., University of Dokuz Eylul.

[30] Parlakkaya, C. (2010). Goce bagli olarak ilkogretim okullarinda yasanan istenmeyen ogrenci davranislarina iliskin ogretmen ve yonetici gorusleri (Teacher and administrator opinions on student misbehaviour in elementary schools depending on immigration). Master diss., University of Sakarya. 
[31] Polat, S. and Rengi, O. (2014). Sinıf ogretmenlerinin kulturel farklılık algıları ve kulturlerarası duyarlılıkları (Primary teachers' perception of cultural diversity and intercultural sensitivity). Zeitschrift fur die Welt der Turken Journal of World of Turks, 6 (3), 135-156.

[32] Saglam, H. I. and Ilksen Kanbur, N. (2017). Sinif ogretmenlerinin multeci ogrencilere yonelik tutumlarının cesitli degiskenler acisından incelenmesi (Investigation attitudes towards refugee Students of class teachers' in terms of several variables). Sakarya University Journal of Education, 7 (2), 310-323.

[33] Selcuk, B. (2014). Gocun egitime ve egitim kurumlarina yansimalari (Mersin il merkezi ornegi) (Reflections on the training of migration and education institutions: Example of Mersin province). Master diss., University of Toros.

[34] Tielman, K., Brok, P. D., Bolhuis, S. and Vallejo, B. (2012). Collaborative learning in multicultural classrooms: A case study of Dutch senior secondary vocational education, Journal of Vocational Education and Training, 64 (1), 103-118.

[35] Topsakal, C., Merey, Z. and Kece, M. (2013). A qualitative study on education rights and problems of immigrant families' children. The Journal of International Social Research 6 (27), 546-60.

[36] UNHCR (United Nations High Commissioner for Refugees). (2014). Syria Regional Response Plan, Turkey. Retrieved from http://www.unhcr.org/syriarrp6/docs/syria-rrp6-turkeyresponse-plan.pdf

[37] UNHCR. (United Nations High Commissioner for Refugees). (2016). Syria Regional Refugee Response Inter-agency Information Sharing Portal. Retrieved from. http://data.unhcr.org/syrianrefugees/regional

[38] UNHCR (United Nations High Commissioner for Refugees). (2017). Retrieved from http://www.unhcr.org/

[39] UNICEF. (2016). Turkiye'deki Suriyeli Cocuklar Bilgi Notu (Information Notes on Syrian Children in Turkey). Retrieved from

http://unicef.org.tr/files/bilgimerkezi/doc/Turkiyedeki\%20Suri yeli\%20Cocuklar_Bilgi\%20Notu\%20Eylu1\%202015

[40] Uzun, E. M. and Eda, B. (2016). Okul oncesi egitim kurumlarindaki Suriyeli siginmaci cocuklarin karsilastiklari sorunlar hakkinda ogretmen gorusleri (The view of teachers' about Syrian refugee children' problems in preschool education institutions). International Journal of Early Childhood Education Studies, 1 (1), 72-83.

[41] Wubbels, T. (2011). An international perspective on classroom management: What should prospective teachers learn? Teaching Education, 22 (2), 113-131.

[42] Yildirim, A. and Simsek, H. (2006). Sosyal bilimlerde nitel arastirma yontemleri (Qualitative research methods in the social sciences). (6. ed). Ankara: Seckin. 